\title{
Psychometric Properties at Indonesian Version of the Sport Anxiety Scale-2: Testing on Elite Athletes of Papua, Indonesian
}

\author{
Miftah Fariz Prima Putra ${ }^{1}{ }^{*}$, Tri Setyo Guntoro ${ }^{1}$, Yos Wandik ${ }^{1}$, Saharuddin Ita $^{1}$, Evi Sinaga ${ }^{1}$, \\ Rodhi Rusdianto Hidayat ${ }^{1}$, Eva Sinaga ${ }^{2}$, Junalia Muhammad ${ }^{1}$, Friska Sari Gracia Sinaga ${ }^{1}$, \\ Remuz Maurens Bertho Kmurawak ${ }^{3}$, Agnes Supraptiwi Rahayu ${ }^{2}$ \\ ${ }^{1}$ Faculty of Sport Sciences, Cenderawasih University, Jayapura, Indonesia \\ ${ }^{2}$ Faculty of Science, Cenderawasih University, Jayapura, Indonesia \\ ${ }^{3}$ Faculty of Medicine, Cenderawasih University, Jayapura, Indonesia
}

Received September 27, 2021; Revised November 15, 2021; Accepted November 27, 2021

\section{Cite This Paper in the following Citation Styles}

(a): [1] Miftah Fariz Prima Putra, Tri Setyo Guntoro, Yos Wandik, Saharuddin Ita, Evi Sinaga, Rodhi Rusdianto Hidayat, Eva Sinaga, Junalia Muhammad, Friska Sari Gracia Sinaga, Remuz Maurens Bertho Kmurawak, Agnes Supraptiwi Rahayu, "Psychometric Properties at Indonesian Version of the Sport Anxiety Scale-2: Testing on Elite Athletes of Papua, Indonesia," International Journal of Human Movement and Sports Sciences, Vol. 9, No. 6, pp. 1477 1485, 2021. DOI: 10.13189/saj.2021.090645.

(b): Miftah Fariz Prima Putra, Tri Setyo Guntoro, Yos Wandik, Saharuddin Ita, Evi Sinaga, Rodhi Rusdianto Hidayat, Eva Sinaga, Junalia Muhammad, Friska Sari Gracia Sinaga, Remuz Maurens Bertho Kmurawak, Agnes Supraptiwi Rahayu (2021). Psychometric Properties at Indonesian Version of the Sport Anxiety Scale-2: Testing on Elite Athletes of Papua, Indonesia. International Journal of Human Movement and Sports Sciences, 9(6), 1477 - 1485. DOI: 10.13189/saj.2021.090645.

Copyright $\bigcirc 2021$ by authors, all rights reserved. Authors agree that this article remains permanently open access under the terms of the Creative Commons Attribution License 4.0 International License

\begin{abstract}
This study aims to adapt and validate the Indonesian version of the Sport Anxiety Scale-2 (SAS-2Id). Data were obtained from a total of 268 (male $=154$ and female $=114$ ) elite athletes of Papua Indonesia with an age range of 16 to 43 years $(\mathrm{M}=22.40 \pm 5.01)$. Furthermore, language adaptation and validation were carried out through a forward-backward translation process using confirmatory factor analysis (CFA). An internal consistency approach was used to test for the reliability based on Construct Reliability (CR). The results evaluate the fit of the models showed that the SAS-2Id fit based on RMSEA, CFI, TLI, and PNFI. The three dimensions of SAS-2Id had standardized coefficient values from .77 to .81 , with a significant $\mathrm{p}$-value of $\leq .001$. The SAS-2Id item factor loading values ranged from .51 to .88 , indicating that it is above the recommended threshold $(\geq .50)$. Furthermore, the reliability test carried out using the internal consistency approach discovered that the dimensions of worry (AVE $=.60)$ and concentration disruption $(\mathrm{AVE}=.50)$ were above the recommended
\end{abstract}

cutoff points. In contrast, the somatic dimension had the lowest value $(\mathrm{AVE}=.35)$. However, from the other two reliability test parameters, it was discovered that the CR and Cronbach's Alpha values were from .73 to .88 and .71 to .88 , respectively, which indicated good reliability values. Therefore, the psychometric property at the Indonesian version of the SAS-2 is a valid and reliable measuring instrument for anxiety levels.

Keywords Trait Anxiety, Adaptation, And Validation, Confirmatory Factor Analysis, Internal Consistency, Indonesian Athletes

\section{Introduction}

Athletes in competition often experience excessive feelings of anxiety [1]. Empirical evidence shows that $63 \%$ experience anxiety when competing [2]. Furthermore, 
it has been reported that more than 50 athletes competing in the Olympic events consulted with psychologists regarding their perceived anxiety complaints [3]. Although anxiety commonly occurs, it is a condition that is very feared by athletes [4], [5] due to its interference with their best performance [6]. Experts have argued that anxiety affects their performance directly infield (see: [7], [8], [9]). Therefore, it is not an exaggeration to state that the athlete's psychological condition (anxiety) is a determining factor, whether the athlete will come out victorious or vice versa [10], [11].

The high or low anxiety felt by athletes negatively impacts their performance in the field [12]. This condition is reinforced by the results of a meta-analysis carried out by Kleine [10], which discovered a correlation between anxiety levels and athlete's performance. In this regard, Humara [13] stated that athletes with moderate anxiety levels produce better performance compared to those with high or low. Therefore, coaches need to know the anxiety level felt by their athletes when competing [14]. There are several techniques to overcoming anxiety, such as progressive relaxation, self-talk, mental imagery, and others [15], [16].

The question is, which technique is suitable to measure or understand the anxiety experienced by athletes? Generally, stress occurring in a person is measured psychometrically using a questionnaire. This method is considered to be more efficient compared to others [15]. Some examples of the questionnaires used to measure anxiety in a general context include the Manifest Anxiety Scale (MAS) and State-Trait Anxiety Inventory (STAI) [10]. Meanwhile, those specific to sports or athletes are measured by The Sport Anxiety (SAS), Competitive Sport Anxiety Inventory (CSAI), and Sport Competition Anxiety Test (SCAT) [17]. Anxiety is also identified using a qualitative approach by observing and interviewing athletes. This method is rarely selected in expressing an athlete's anxiety.

In Indonesia, several studies have been carried out on anxiety. A total of 64 relevant articles were discovered from the search for scientific articles carried out on a search engine made by the Indonesian government with the name "Garba rujukan digital (garuda)" on a website https://garuda.ristekbrin.go.id/ with keywords "athlete AND anxiety" and "sports AND anxiety" in the period 2010-2021. These articles were analyzed, and it was discovered that studies often implement instruments from abroad such as the Sport Anxiety Scale (SAS), Competitive Sport Anxiety Inventory (CSAI), Sport Competition Anxiety Test (SCAT), Hamilton Anxiety Rating Scale (HARS), Taylor Manifest Anxiety Scale (TMAS) and Sport Interference Checklist (SIC).

Unfortunately, during the analysis of more deeply related use of sports anxiety instruments from abroad, we found that no article provided details on how the process of cultural adaptation and language translation was carried out, whether culture and language adaptation procedures refer to the international standard [18], [19], [20]. The process is essential to be acknowledged in the context of scientific publications [21]. Language-culture adaptation and validity testing are absolute requirements that need to be passed. Therefore, these instruments produce accurate, precise, and objective data [22]. This situation implies that in Indonesia's context of sports science studies, especially those related to athlete anxiety, they are limited in the absence of internationally accepted standard procedures in adapting and validating instruments. Similarly, Sperber states that the challenge of using different language instruments lies in the translation quality [23].

SAS-2 is not only an instrument often used for study in Indonesia; however, it has been translated into six different languages, including Spanish [24], Portuguese [25], Flemish [26], Malaysia [27], Brazillian [28], and Korean [29]. Furthermore, the implementation of SAS as a measuring instrument by international students is not a hyperbole.

Based on the above description, this study aims to obtain a valid and reliable measuring instrument for sports anxiety in Indonesia. They include adapting language-culture and validating The Sport Anxiety Scale-2 (SAS-2) tool using the internationally accepted standard protocols. This study is the first study carried out in Indonesia concerning this topic. Therefore, the results will be beneficial to studies, coaches, and stakeholders interested in athlete anxiety.

\section{Materials and Methods}

\section{Participants}

The subjects involved in this study were 268 (male = 154 and female $=114$ ) elite athletes from Papua Indonesia with an age range of 16 to 43 years $(M=22.40 \pm 5.01)$, undergoing training camps for the most prominent national sports event in Indonesia, namely PON (National Sports Week). Thirty-seven sports have competed in PON, and respondents are taken based on four sports criteria: measured, precision, game, and martial arts. The criteria were selected for athletics, rowing, and swimming (measured), archery and shooting (precision), volleyball, basketball, and soccer (games), Kempo, Muaythai, Boxing, Tarung Derajat, and Pencak silat (martial arts). All athletes who are in the sport were involved as respondents.

\section{Instruments}

The Sport Anxiety Scale (SAS) was developed by Smith, Smoll, and Schutz [30]. It was later revised by Smith, Smoll, Cumming, and Grossbard [31] and became Sport Anxiety Scale-2 (SAS-2). Generally, there was no difference in the number of anxiety dimensions revealed 
between the initial and revised SAS versions. Furthermore, the difference between the first version of SAS and the revision lies in the number of statement items. The 21 items in the initial SAS version [32], [30] became 15 in the revised version [31]. There were three anxiety dimensions measured by SAS-2, including one somatic and two types of cognitive anxiety such as worry and concentration disruption [32]. Therefore, SAS-2 consisted of 15 items and was divided into three successive scales. They are somatic anxiety (e.g., My body feels tense), worry (e.g., I worry that I will not play well), and concentration disruption (e.g., It is hard to concentrate on the competition) [31]. In addition, there were four alternative answers in SAS-2, namely (1) not at all, (2) a little bit, (3) pretty much, and (4) very much.

\section{Procedure}

The procedures followed are explained briefly: First, two people translated the measuring instrument from English to Indonesian. Second, after obtaining the translation, we submitted it to an expert in sports psychology to review its accuracy. Third, after the Indonesian version of the measuring instrument was examined, it was readability tested on the Indonesian version of the SAS-2 instrument was carried out by Indonesian language experts and sports students to check the instructions and readability level of the items (see Appendix). Fourth, it was continued by carrying out field tests involving elite athletes from Papua Indonesia who are various sports members. Fifth, the results of the instrument testing were analyzed using the CFA to determine the appropriateness and goodness of the property at the Indonesian version of the Sport Anxiety Scale-2 (SAS-2Id) for measuring the anxiety levels in athletes.

\section{Statistical analysis}

In addition, the study data were analyzed using the Confirmatory Factor Analysis (CFA) approach. Validity through this approach is also called construct validity, which includes testing the internal structure of the measuring instrument [22]. Furthermore, this study was guided by several fit indexes to test the model fitness. The fit of the models' evaluation used the Chi-square and p-value, Root Mean Square Error of Approximation (RMSEA), Comparative Fit Index (CFI), Tucker-Lewis Index (TLI), and Parsimonious Normal Fit Index (PNFI).

The criteria used in accepting a fit model for the chi-square include p-value $\geq .05$, RMSEA $\leq .08$, CFI and TLI $\geq .90$, PNFI .60-.90 [33], [34], [35], [36]. If the model meets the fit requirements, it is continued by looking at the factor loading on each item [33] compiling the SAS-2Id construct. Meanwhile, the criteria used were $\lambda \geq .50$. Therefore, the item was declared acceptable [36], [33].

For reliability, this study carried out tests using an internal consistency approach through Constructor Composite Reliability (CR) and Average Variance Extracted (AVE). The minimum value sets to indicate the construct acceptance in the CR and AVE were 0.7 and 0.5 , respectively [33], [36]. Furthermore, the Cronbach 'Alpha coefficient was also used in the SAS-2Id reliability test. All analysis in this study was carried out with the IBM Amos version 26 and IBM SPSS version 26 programs.

\section{Results}

The descriptive study results (Table 1) show that trait worry had the highest average value $(10.93 \pm 4.18)$, followed by concentration disruption $(8.82 \pm 3.25)$ and somatic $(7.63 \pm 2.55)$. The maximum value of trait bodily (16) was smaller than the other two traits, each of which had a score of 20. Overall, the mean score of SAS-2Id was $27.36 \pm 8.61$, with a minimum and maximum score of 15 and 51, respectively.

Table 1. Results of descriptive analysis $(\mathrm{N}=268$; Male $=154$, Female $=114$ )

\begin{tabular}{|c|c|c|c|c|c|}
\hline Trait & N & M & S.D & Min & Max \\
\hline Somatic & 268 & 7.62 & 2.55 & 5 & 16 \\
\hline Worry & 268 & 10.93 & 4.18 & 5 & 20 \\
\hline $\begin{array}{c}\text { Concentration } \\
\text { Disruption }\end{array}$ & 268 & 8.82 & 3.25 & 5 & 20 \\
\hline Score total & 268 & 27.36 & 8.61 & 15.00 & 51.00 \\
\hline
\end{tabular}

Note: M: Mean, S.D: Standard Deviation, Min: Minimum Score, Max: Maximum Score

The test results (see table 2) show that four parameters (RMSEA, CFI, TLI, and PNFI) indicated an acceptable fit to the data. Meanwhile, one parameter (Chi-square) revealed the model is not fit. According to $\mathrm{Hu}$ and Bentler [33], Chi-square is very sensitive to sample size. The greater the number of samples used, the chi-square produces a significant difference between the model tested and the empirical data. Therefore, even though its parameter indicated that the model did not fit, the other four indicated fit models. Thus, the SAS-2Id with three subscales, namely somatic anxiety, worry, and concentration disruption, was stated as a fit model.

Table 2. Fit test results for the SAS-2Id model

\begin{tabular}{|c|c|c|c|}
\hline Parameter & Output & Criteria & Decision \\
\hline$\chi^{2} / \mathrm{df} / \mathrm{p}$ & $225.78 / 87 / .0001$ & $\geq .05$ & Unfit \\
\hline RMSEA & .077 & $\leq .08$ & Fit \\
\hline CFI & .923 & $\geq .90$ & Fit \\
\hline TLI & .91 & $\geq .90$ & Fit \\
\hline PNFI & .731 & $.60-.90$ & Fit \\
\hline
\end{tabular}

Note: $\chi^{2}$ : Chi-square, RMSEA: Root Mean Square Error of Approximation, CFI: Comparative Fit Index, TLI: Tucker-Lewis Index, PNFI: Parsimonious Normal Fit Index

In Figure 1, three dimensions were tested, namely 
somatic anxiety, worry, and concentration disruption. It shows a form of sports anxiety because the standardized coefficient had values from .77 to .81 with a p-value of $\leq .001$. Furthermore, the factor loading of all items had a value of $\lambda \geq .50$, and there were eight items with a value of $\lambda \geq .70$. Therefore, this showed that each item arranged in SAS-2Id had a good factor loading.

After testing the model and analyzing factor loading, the reliability test was conducted using an internal consistency approach. Hair et al. [35] explained that the reliability test in CFA analysis could be carried out with Construct Reliability (CR) and Average Variance Extracted (AVE). High construct reliability (CR $\geq .07$ and $\mathrm{AVE} \geq .50$ ) indicates internal consistency in the measuring instrument. This means that all items consistently represent the same latent constructs. Furthermore, the Cronbach's Alpha was used in the reliability test of this study.

The internal consistency approach was used to test the reliability of the SAS-2Id measuring instrument. The results are presented in Table 3. Furthermore, the three dimensions of SAS-2Id (somatic anxiety, worry, and concentration disruption) had a CR value of $\geq .70$, indicating good reliability. For the AVE value, only the somatic dimension was under the criteria $(.35<.50)$, while the other two were above the recommended cutoff points (AVE $\geq .50$ ). Furthermore, the reliability test using Cronbach's Alpha showed similar results as CR. The reliability value was relatively high in the range from .71-.88 in the three dimensions tested.

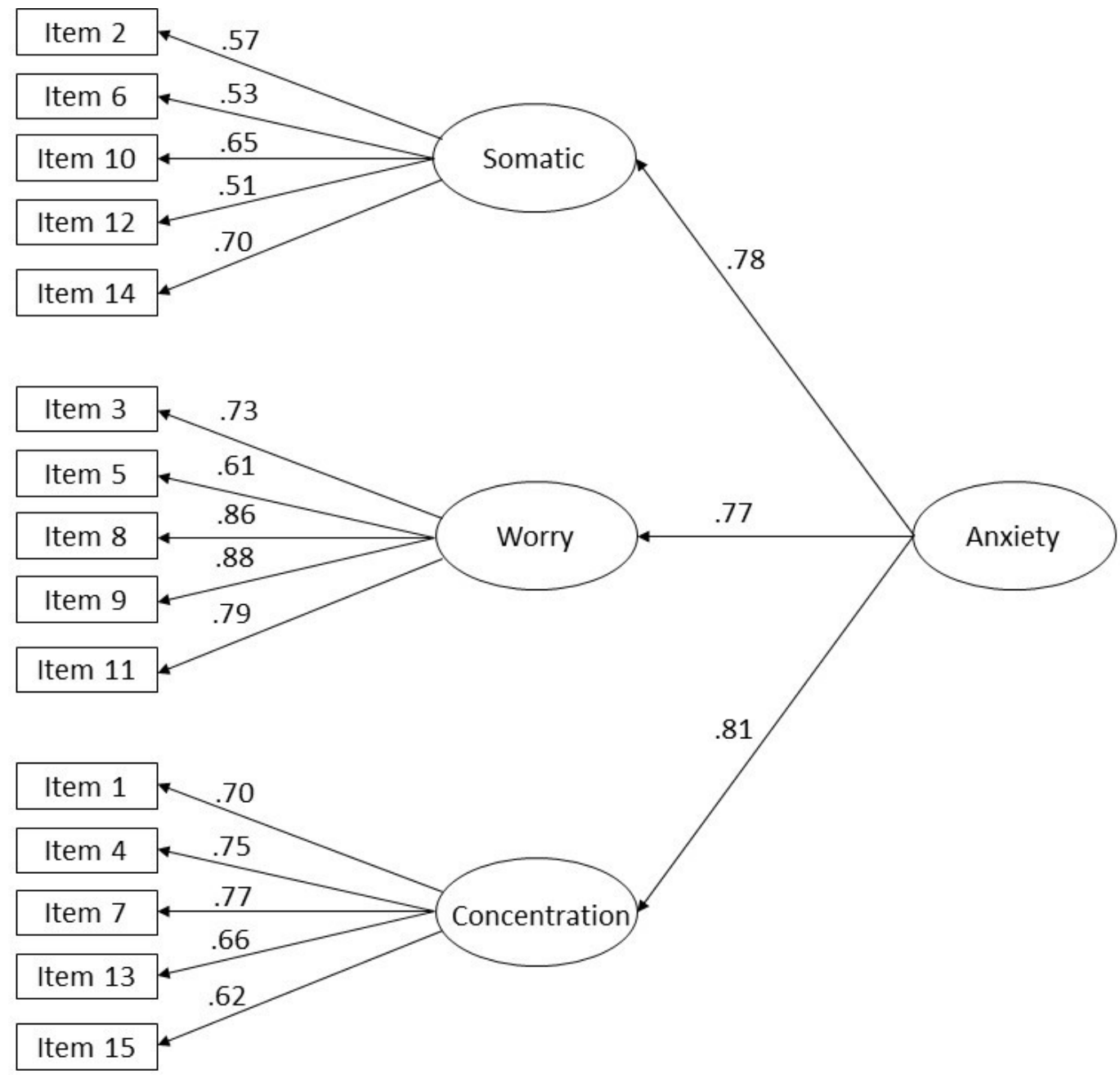

Figure 1. SAS-2Id CFA results with three factors. The values in the figure are standardized coefficients 
Table 3. SAS-2Id reliability test results

\begin{tabular}{|c|c|c|c|c|c|c|}
\hline Dimensions & $\lambda$ & $\lambda^{2}$ & $e$ & CR & AVE & $\mathbf{C A}$ \\
\hline Somatic anxiety & & & & .73 & .35 & .71 \\
\hline Item2 & .57 & .33 & .67 & & & \\
\hline Item6 & .53 & .28 & .72 & & & \\
\hline Item 10 & .65 & .42 & .58 & & & \\
\hline Item12 & .51 & .26 & .74 & & & \\
\hline Item14 & .70 & .48 & .52 & & & \\
\hline Total & 2.95 & 1.76 & 3.24 & & & \\
\hline Worry & & & & .88 & .60 & .88 \\
\hline Item3 & .73 & .53 & .47 & & & \\
\hline Item5 & .61 & .37 & .63 & & & \\
\hline Item8 & .86 & .74 & .26 & & & \\
\hline Item9 & .88 & .77 & .23 & & & \\
\hline Item11 & .79 & .62 & .38 & & & \\
\hline Total & 3.86 & 3.02 & 1.98 & & & \\
\hline \multicolumn{2}{|c|}{ Concentration Disruption } & & & .83 & .50 & .82 \\
\hline Item1 & .70 & .49 & .51 & & & \\
\hline Item4 & .75 & .56 & .44 & & & \\
\hline Item7 & .77 & .59 & .41 & & & \\
\hline Item13 & .67 & .44 & .56 & & & \\
\hline Item15 & .62 & .39 & .61 & & & \\
\hline Total & 3.50 & 2.47 & 2.53 & & & \\
\hline
\end{tabular}

Note: $\lambda$ : Factor loading, $\lambda^{2}$ : The squares of the factor loading, $e$ : Error, CR: Construct Reliability, AVE: Average Variance Extracted, CA: Cronbach's Alpha

\section{Discussion}

This study adapted the language and tested the accuracy of the Indonesian version of the Sport Anxiety Scale-2 (SAS-2Id) instrument model, using confirmatory factor analysis (CFA). A construct validity test is carried out after the language adaptation process is completed. According to the above results, SAS-2Id had three subscales and fifteen statement items with a fit model based on four parameters: RMSEA, CFI, TLI, and PNFI. These test results align with the original SAS-2 version, which shows the fit model on several parameters used: chi-square, RMSEA, CFI, NNFI, and RMSEA 90\% Cls [31]. Furthermore, this study was in line with Silva-Rocha and Osório [28] and Silva-Rocha et al., [37]. It stated that the SAS-2 property in the Brazilian language had a fit model based on parameters CFI, TLI, RMSEA, and WRMR. The same result was also found when adapted in Spanish, which reported that the psychometric property of SAS-2 is a fit model based on the chi-square, CFI, TLI, RMSEA, and ECVI parameters [24].

Furthermore, testing the three dimensions in SAS-2Id, namely somatic anxiety, worry, and concentration disruption, showed coefficient values of .78, .77, and .81 respectively, and significant at $\mathrm{p}$-value $=.001$. These results indicated that the dimensions measure anxiety in sports. Also, it is in line with the study carried out by Smith et al., [31] when revising the first version of SAS. It is stated that the standardized coefficient values of the three dimensions were .75 to .84 . Furthermore, examining the dimensions with scores on the first version of the SAS found a coefficient value of .69 to .90 with a significance $\mathrm{p}$-value $\leq .01$. Therefore, the results of this study reinforce the results of previous which examined all three dimensions of anxiety in SAS [30], [31], [37].

Furthermore, the CFA test results also discovered a fairly high factor loading value $(\geq .50)$ for each item in the SAS-2Id. According to Ghozali [35], the factor loading value of $\geq .50$ indicated that the item is acceptable. On the somatic anxiety sub-scale, the smallest and largest factor loading values were .51 (Som4 [item12]) and .70 (Som5 [item14]), respectively. For the worry sub-scale, the smallest and largest factor loading values were 0.61 (Wor2 [item5]) and .88 (Wor4 [item9]), respectively. On the concentration disruption sub-scale, the smallest and largest factor loading values were .62 (ConDis5 [item15]) and .77 (ConDis3 [item7]) respectively. From the factor loading value, it can be observed that there are items with loading values $\geq .70$. Furthermore, Azwar [22] and Ghozali [35] stated that the factor loading value $\geq .70$ indicates that the item has good validity. Thus, the fifteen statement items in the SAS-2Id have the factor loading values above the requirements [22], [35], [36].

The results based on the factor loading value are in line with the original version. However, the finding is slightly different from this study's results. It showed that there are seven and eight items with loading values of $\geq .50$ and $\geq .70$, respectively [31]. Furthermore, the SAS-2 test in the Spanish version discovered that nine and six items had loading values of $\geq .70$ and $\geq .50$, respectively [24]. Also, studies involving Brazilian athletes found a higher result, namely those adapting the Brazilian version of SAS-2, 
finding thirteen items having a loading value of $\geq .70$ and seven items having a loading value of $\geq .50$ [37].

Overall, the item factor loading values of SAS-2Id moved from .51 to .88 . Therefore, these results indicated that the Indonesian version of SAS-2 psychometric property with three subscales and fifteen statement items is valid in measuring athletes' level of sports anxiety. This study adds to the empirical evidence that SAS-2 is a valid measuring tool like other studies that performed language adaptation and validation testing in the past (see for example [24], [25], [26], [27], [28], [29].

Furthermore, the reliability test results using internal consistency discovered that two dimensions had an AVE value of $\geq .50$ (worry and concentration disruption). In contrast, the somatic dimension had a low value (AVE $=.35$ ). According to Hair et al. [36], the recommended AVE value is $\geq .50$. Therefore, on the somatic anxiety subscale, the value does not match the specified criteria. AVE value $\leq .50$ was found due to the four items present in the somatic anxiety with a factor loading of $\leq .70$. The four items consist of item 2 ("My body feels tense"), 6 ("I feel tense in my stomach"), 10 ("My muscles feel shaky"), and 12 ( "My stomach feels upset" ). Furthermore, according to Ghozali [35], a loading value of $\leq .70$ will pull the AVE value below .50. This result is in line with the study carried out by Cho et al. [29]. It discovered that the AVE value on the somatic anxiety dimension was below .50 .

However, the internal consistency of SAS-2Id based on $\mathrm{CR}$ has a fairly high-reliability value. The somatic anxiety subscale obtained $\mathrm{CR}=.73$, for worry $\mathrm{CR}=.88$, and concentration disruption $\mathrm{CR}=.83$. Concerning the $\mathrm{CR}$ value, Hair et al., [36] stated that the CR value of $\geq 0.7$ is good reliability, while between 0.6 and 0.7 is acceptable reliability. Regarding these criteria, the three SAS-2Id subscales (somatic anxiety, worry, and concentration disruption) have satisfactory internal consistency reliability. Furthermore, the Cronbach's Alpha $(\alpha)$ coefficient also showed similar results. Each subscale has a reliability coefficient value of .71-.88. Kaplan and Sacuzzo [38] recommend that a good reliability value is $\geq .70$. Therefore, the Indonesian version of the SAS-2 property (SAS-2Id) has good internal consistency.

These results are in line with the reliability test of the original version, which discovered the coefficient value of Cronbach's Alpha $\geq .80$ [31]. Furthermore, testing SAS-2 psychometric properties on Brazilian also discovered internal consistency values that were almost similar to the study, namely $\alpha=.73-.88$ [28]. Previous studies that tested SAS in French also discovered similar results. The reliability coefficient values ranged from 0.86 to 0.89 [40]. This indicates that SAS-2 in Indonesian has a high value of internal consistency in measuring anxiety in athletes or the context of sports. Therefore, the psychometric properties of SAS-2Id can be used to measure trait anxiety (trait somatic anxiety, trait worry, and trait concentration disruption) when subjected to athletes.

Even though the language adaptation and the construct validity test of the SAS-2 instrument have been carried out into the Indonesian version (SAS-2Id), this study had several limitations. First, there were no convergent and discriminant validity tests. Convergent validity relates to how a measure is positively correlated with other measures of the same construct. Meanwhile, the discriminant validity tests the extent to which a construct differs from another [22]. In construct validity, testing convergent and discriminant validity is essential to obtain a psychometric property of a good and reliable measuring instrument. The test was carried out by Smith et al. [30] and Smith et al., [31] while developing and revising SAS. Also, it was carried out by Silva-Rocha et al. [37] when testing SAS-2 properties on Brazilians. Secondly, the research subjects were used only to represent the characteristics of elite Indonesian Papuan athletes and not other characteristics. For example, student-athletes, non-elite athletes, and do, not group based on adolescence, early adulthood, middle adulthood, individual sport athletes, and Team sport athletes as done by Lundqvist and Hassmén [40].

\section{Conclusion and Suggestions}

This study concluded that the fit of the models showed that the SAS-2Id fit based on RMSEA $=.077, \mathrm{CFI}=.923$, TLI $=.910$, and PNFI $=.731$. The three dimensions of SAS-2Id had standardized coefficient values from .77 to .81 , with a significant $\mathrm{p} \leq .001$. The SAS-2Id item factor loading values ranged from .51 to .88 , indicating above the recommended threshold $(\geq .50)$. Furthermore, the reliability test carried out using the internal consistency approach discovered that the dimensions of worry $(\mathrm{AVE}=.60)$ and concentration disruption (AVE $=.50$ ) were above the recommended cutoff points. However, the other two reliability test parameters found that the CR and Cronbach's Alpha values were from .73 to .88 and .71 to .88 , respectively, which indicated good reliability values. Thus, this study concludes that the psychometric property of the Indonesian version of SAS-2 (SAS-2Id), with three subscales and fifteen statement items, is valid and reliable for measuring athlete anxiety. With this evidence, the following research in Indonesia that seeks to uncover and examine aspects of anxiety can use the SAS-Id that has been tested in this study. 


\section{Appendix}

Scale items.

\begin{tabular}{|c|c|}
\hline No & $\begin{array}{c}\text { Sport Anxiety Scale-2 } \\
\text { Indonesian Sport Anxiety Scale-2 }\end{array}$ \\
\hline 1 & $\begin{array}{l}\text { It is hard to concentrate on the game } \\
\text { Sangat sulit berkonsentrasi dalam pertandingan }\end{array}$ \\
\hline 2 & $\begin{array}{l}\text { My body feels tense } \\
\text { Tubuh saya terasa tegang }\end{array}$ \\
\hline 3 & $\begin{array}{l}\text { I worry that I will not play well } \\
\text { Saya khawatir tidak dapat bermain dengan baik }\end{array}$ \\
\hline 4 & $\begin{array}{l}\text { It is hard for me to focus on what I am supposed to do } \\
\text { Sulit bagi saya untuk dapat fokus pada apa yang seharusnya dilakukan }\end{array}$ \\
\hline 5 & $\begin{array}{c}\text { I worry that I will let others down } \\
\text { Saya khawatir akan membuat orang lain kecewa }\end{array}$ \\
\hline 6 & $\begin{array}{l}\text { I feel tense in my stomach } \\
\text { Perut saya terasa kram }\end{array}$ \\
\hline 7 & $\begin{array}{c}\text { I lose focus on the game } \\
\text { Saya kehilangan fokus dalam pertandingan }\end{array}$ \\
\hline 8 & $\begin{array}{l}\text { I worry that I will not play my best } \\
\text { Saya khawatir tidak bermain dalam performa terbaik }\end{array}$ \\
\hline 9 & $\begin{array}{c}\text { I worry that I will play badly } \\
\text { Saya khawatir akan bermain dengan buruk }\end{array}$ \\
\hline 10 & $\begin{array}{c}\text { My muscles feel shaky } \\
\text { Otot-otot saya terasa gemetar }\end{array}$ \\
\hline 11 & $\begin{array}{l}\text { I worry that I will mess up during the game } \\
\text { Saya khawatir performa saya jelek selama pertandingan }\end{array}$ \\
\hline 12 & $\begin{array}{l}\text { My stomach feels upset } \\
\text { Perut saya terasa mual }\end{array}$ \\
\hline 13 & $\begin{array}{c}\text { I cannot think clearly during the game } \\
\text { Saya tidak dapat berpikir dengan baik selama pertandingan }\end{array}$ \\
\hline 14 & $\begin{array}{l}\text { My muscles feel tight because I am nervous } \\
\text { Otot-otot saya terasa kram karena saya gugup }\end{array}$ \\
\hline 15 & $\begin{array}{l}\text { I have a hard time focusing on what my coach tells me to do } \\
\text { Saya sulit memfokuskan pada apa yang dikatakan pelatih tentang yang harus saya lakukan }\end{array}$ \\
\hline
\end{tabular}

Somatic: Items 2, 6, 10, 12, 14; Worry: Items 3, 5, 8, 9, 11; Concentration Disruption: Items 1, 4, 7, 13, 15. 


\section{REFERENCES}

[1] Vealey, R. S, "Advancements in competitive anxiety research: Use of the sport competition anxiety test and the competitive state anxiety inventory-2," Anxiety Research, vol. 2, no. 4, pp. 243-261, 1990. DOI: $10.1080 / 08917779008248732$.

[2] Kumbara, H., Metra, Y., Ilham, Z, "Analisis tingkat kecemasan (anxiety) dalam menghadapi pertandingan atlet sepak bola kabupaten banyuasin pada Porprov 2017 [Level of anxiety among Banyuasin soccer athletes in 2017 regional competition]," Jurnal Ilmu Keolahragaan, vol. 17, no. 2 , pp. 28-35, 2018, DOI: 10.24114/jik.v17i2.12299.

[3] Murphy, S. M, "The On-Site Provision of Sport Psychology Services at the 1987 U.S. Olympic Festival," The Sport Psychologist, vol. 2, no. 4, pp. 337-350, 1988, DOI: 10.1123/tsp.2.4.337.

[4] Karageorghis, C., Terry, P, "Inside sport psychology," Human Kinetics Publisher, Inc., 2011.

[5] Ivaskevych, D., Fedorchuk, S., Petrushevskyi, Y., Borysova, O., Ivaskevych, O., Kohut, I., Marynych, V., Tukaiev, S, "Association between competitive anxiety, hardiness, and coping strategies: a study of the national handball team," Journal of Physical Education and Sport, vol. 20, no. 1, pp. 359-365, 2020, DOI: 10.7752/jpes.2020.s1051.

[6] Sukadiyanto, "Perbedaan Reaksi Emosional Antara Olahragawan Body Contact dan Non-Body Contact [The difference of emotional reaction between body contact athletes and non-body contact athletes]," Jurnal Psikologi, vol. 33, no. 1, pp. 50-62, 2006, DOI:10.22146/jpsi.7085.

[7] Correia, M., Rosado, A, "Fear of failure and anxiety in sport," Analise Psicologica, vol. 36, no. 1, pp. 75-86, 2018, DOI: $10.14417 /$ ap.1193.

[8] Correia, M., Rosado, A, "Anxiety in Athletes: Gender and Type of Sport Differences," International Journal of Psychology Research, vol. 12, no. 1, pp. 9-17, 2019, DOI: 10.21500/20112084.3552.

[9] Singh, V., Punia, S, "Measurement of competition level anxiety of university level players by using scat in north zone in India," International Journal of Yoga, Physiotherapy and Physical Education, vol. 3, no. 2, pp. 07-09, 2018, DOI: 10.1080/026404199365867

[10] Kleine, D, "Anxiety and sport performance: A meta-analysis," Anxiety Research, vol. 2, no. 2, pp. 113131, 1990, DOI: 10.1080/08917779008249330

[11] Palazzolo, J, “Anxiety and performance," Encephale, vol. 46, no. 2, pp. 158-161, 2020, DOI: 10.1016/j.encep.2019.07.008

[12] Supriyatna, Y., Kusmaedi, N., Hidayat, Y., Hambali, B, "Regression Equation Model of Motivation, Self-Confidence, and Anxiety Variables in Mastering Badminton Games Learning Outcome Test," Jurnal Pendidikan Jasmani Dan Olahraga, vol. 4, no. 2, pp. 111117, 2019, DOI: 10.17509/jpjo.v4i2.18677
[13] Humara, M, "The Relationship Between Anxiety and Performance: A Cognitive-Behavioral Perspective," Athletic Insight: The Online Journal of Sport Psychology, vol. 1, no. 2, pp. 1-14, 1999.

[14] Dimyati, "Psikologi olahraga: metode latihan mental bola basket [Sport psychology: the methodology of mental training for basketball]," UNY Press, 2018.

[15] Jannah, M, "Kecemasan Olahraga: teori, pengukuran dan latihan mental [Sport anxiety: theory, measurement, and mental training]," Unesa University Press, 2016.

[16] Jarvis, M, "Sport psychology,” Routledge, 1999.

[17] Mellalieu, S., Hanton, S., Fletcher, D, “A competitive anxiety review: Recent Directions in Sport Psychology Research,” Nova Science Publishers, Inc., 2009.

[18] ITC, "ITC Guidelines for Translating and Adapting Tests (Second Edition)," International Journal of Testing, 2017, DOI:10.1080/15305058.2017.1398166.

[19] Gudmundsson, E, "Guidelines for translating and adapting psychological instruments," Nordic Psychology, vol. 61, no. 2, pp. 29-45, 2009, DOI: 10.1027/1901-2276.61.2.29.

[20] Sousa, V. D., Rojjanasrirat, W, “Translation, adaptation and validation of instruments or scales for use in cross-cultural health care research : a clear and user-friendly guideline," Journal of Evaluation in Clinical Practice, vol. 17, no. 2, pp. 268-274, 2011, DOI: 10.1111/j.1365-2753.2010.01434.x.

[21] Ohrbach, R., Bjorner, J., Metric, Q., Jezewski, M., John, M T., \& Lobbezoo, F. (2013). Guidelines for establishing cultural equivalency of Instruments, Online available from https://ubwp.buffalo.edu/

[22] Azwar, S, "Reliabilitas dan validitas [validity and reliability of instrument]," Pustaka pelajar, 2012.

[23] Sperber, A. D, "Translation and Validation of Study Instruments for Cross-Cultural Research," Gastroenterology, vol. 126, no. 1, pp. 124-128, 2004, DOI: 10.1053/j.gastro.2003.10.016.

[24] Ramis, Y., Torregrosa, M., Viladrich, C., Cruz, J, "Adaptation and validation of the Spanish version of the Sport Anxiety Scale SAS-2 for young athletes," Psicothema, vol. 22, no. 4, pp. 1004-1009, 2010.

[25] Sousa, C., Gomes, M., Torregrosa, M., Viladrich, C., Cruz, $\mathrm{J}$, "Psychometric properties of the MCSYS, AGSYS and SAS-2: preliminary validation into Portuguese," Proceeding of the 13th FEPSAC European Congress of Sport Psychology, Madeira Island, Portugal, 12-17 July, 2011, https://fepsac.com/

[26] Jannes, C. R., De Pelsemaeker, D., De Deken, D., Van Damme, D, "Psychometric properties of the flemish version of the sport anxiety scale-2," Proceeding of the 13th FEPSAC European Congress of Sport Psychology, Madeira Island, Portugal, 12-17 July, 2011, https://fepsac.com/

[27] Hashim, H. A., Shaharuddin, S. S., Hamidan, S., Grove, J. R, "A Multisample Analysis of Psychometric Properties for the Malaysian Adapted Sport Anxiety Scale-2 Among Youth Athletes," Psychological Reports, vol. 120, no. 1, pp. 141-157, 2017, DOI: 10.1177/0033294116685868. 
[28] Silva-Rocha, V. V., Osório, F. d. L, "Cross-cultural adaptation of the Sport Anxiety Scale-2 (SAS-2) for the Brazilian context," Trends in Psychiatry and Psychotherapy, vol. 39, no. 3, pp. 202-206, 2017, DOI: 10.1590/2237-6089-2017-0027.

[29] Cho, S., Choi, H., Eklund, R. C., Paek, I, "Validation and Reliability of the Korean Version of the Sport Anxiety Scale-2," Journal of Human Kinetics, vol. 61, no. 1, pp. 217-225, 2018, DOI: 10.1515/hukin-2017-0138.

[30] Smith, R., Smoll, F., Schutz, R, "Measurement and correlates of sport-specific cognitive and somatic trait anxiety: The sport anxiety scale," Anxiety Research, vol. 2, no. 4, pp. 263-280, 1990, DOI: 10.1123/jsep.28.4.479

[31] Smith, R., Smoll, F., Cumming, S., Grossbard, J, "Measurement of Multidimensional Sport Performance Anxiety in Children and Adults: The Sport Anxiety Scale-2," Journal of Sport \& Exercise Psychology, vol. 28, no.4, pp. 479-501. 2006, DOI: 10.1080/08917779008248733

[32] Dunn, J.G.H., Dunn, J.C., Wilson, P., Syrotuik, D. G, "Reexamining the Factorial Composition and Factor Structure of the Sport Anxiety Scale," Journal of Sport \& Exercise Psychology, vol. 22, no. 2, pp. 183-193, 2000, DOI: 10.1123 jsep.22.2.183

[33] Hu, L., Bentler, P, "Cutoff criteria for fit indexes in covariance structure analysis: Conventional criteria versus new alternatives," Structural Equation Modeling, vol. 6, no. 1, pp. 1-55, 1999, DOI: 10.1080/10705519909540118

[34] Brown, T, "Confirmatory Factor Analysis for Applied Research, $2^{\text {nd }}$ ed.," The Guilford Press, 2015.

[35] Ghozali, I, "Model persamaan struktural: Konsep dan aplikasi dengan program Amos 24 ( $7^{\text {th }}$ ed.) [model of structural function: theory and aplication with the Amos 24]," Badan Penerbit Universitas Diponegoro, 2017.

[36] Hair, J. F., Black, W. C., Babin, B. J., Anderson, R. E, “Multivariate Data Analysis, $8^{\text {th }}$ ed.," Cengage, 2019.

[37] Silva-rocha, V.V., Sousa, D.A.D., Osório, F.L, Psychometric "Properties of the Brazilian Version of the Sport Anxiety Scale-2," Front. Psychol, vol. 10, no. 806, pp. 1-9, 2019, DOI: 10.3389/fpsyg.2019.00806.

[38] Kaplan, R., Sacuzzo, D, "Psychological Testing, $7^{\text {th }}$ ed.," Cengage Learning, 2008.

[39] Marcel, J., Paquet, Y, "French validation of the modified version of the SAS," L'Encéphale, vol. 36, no. 2, pp. 116121. 2010, DOI: 10.1016/j.encep.2009.05.006.

[40] Lundqvist, C., \& Hassén, P. "Competitive State Anxiety Inventory-2 (CSAI-2): Evaluating the Swedish version by confirmatory factor analyses," Journal of Sports Sciences, vol. 23, no. 7, pp. 727-736, 2005, DOI: https://doi.org/10.1080/02640410400021484. 